Poznań

\title{
The influence of ICT on modern democracy. Selected dilemmas of electronic democracy ${ }^{1}$
}

\begin{abstract}
Due to rapid development of Information and Communication Technologies in all areas of public life, the influence of ICT on democracy has been becoming over the last years an increasingly popular research subject. Application of modern technologies influences work, education, trade, services and social relations on the professional, public and private space. ICTs are also applied to facilitate (and adapt technologically) processes that occur between political institutions, political parties and politicians - and voters. ICTs are increasingly applied in providing information and communications, as well as in elections. Taking all this into consideration, one can speak about a new paradigm of democracy assisted by electronic technologies. Next to traditional democracy, electronic democracy is becoming a popular concept defined in terms of information and communication technologies applied in order to increase citizen participation in democratic processes, both as concerns the quantity and the form of actual impact exerted by individuals on public institutions.

The main objective of this study is to answer questions about the most important dilemmas related to e-democracy, and the most frequent concerns, and thereby challenges, posed by this new form of governance. These considerations are conducted in the context of the analysis of the influence of ICT on democratic principles, as well as citizen participation. The theoretical foundation for the analysis is provided by the theories by Tero Päivärinta and Øystein Sæbø, Joachim Åström, and Jan A. G. M. van Dijk. The paper is divided into several parts: the first one discusses the character of electronic democracy and its models, the second concerns the issue of ICT-assisted participation, and the third is devoted to the different dilemmas and challenges posed by electronic democracy.
\end{abstract}

Key words: electronic democracy, e-democracy, ICT, e-participation

t cannot be doubted that modern societies are facing the era of 'electronic democracy' and the transformations caused by the influence of Information and Communication Technologies (ICTs) on democracy is unavoidable and irreversible. Lawrence K. Grossman reckons that interactive telecommunications have allowed tens of millions of people scattered across vast expanses to obtain the information necessary to take over the tasks of governments, gain access to the world of politics and reclaim at least some control over their fate and assets, which is believed by many to be abused by elected leaders (Grossman, 1995a, p. 287). Grossman also believes that what he calls an electronic revolution is possible on account of ensuring political equality to all citizens and advancement of new means of telecommunications (Grossman, 1995b, pp. 22-26). This form of democracy appears to be among the new ways of communicating with citizens (London, 1995, pp. 3-4).

${ }^{1}$ This article has been written within the research project: $\boldsymbol{E}$-voting as an alternative way of voting procedures in national elections. Experiences of selected countries and prospects for implementation e-voting in Poland (E-voting jako alternatywna procedura glosowania w elekcjach państwowych. Doświadczenia wybranych państw a perspektywy wdrożenia e-glosowania w Polsce) - financed by the National Science Center in Poland UMO-2014/15/B/HS5/01358. 
ICTs seem a significant element of the globalization and informatization process. They are applied in practically every field of modern life, ranging from economy, entertainment, trade and banking to politics. New technologies have an enormous impact on the evolution of the state, its institutions and on society, where they are used for information, education and facilitation of the operations of state entities and institutions. ICTs are also applied to facilitate (and adapt technologically) processes that occur between political institutions, political parties and politicians - and voters. ICTs are increasingly applied in providing information and communications, as well as in elections. Taking all this into consideration, one can speak about a new paradigm of democracy assisted by electronic means, such as the Internet, digital television, cellular telephony and so on. Next to traditional democracy, electronic democracy is becoming a popular subject of academic studies and the debates of experts and political practitioners who seem to realize that this form of governance, which is the outcome of technological progress, is, at least to some extent, unavoidable.

The main objective of this study is to answer questions about the most important dilemmas related to e-democracy, and the most frequent concerns, and thereby challenges, posed by this new form of governance. These considerations are conducted in the context of the analysis of the influence of ICT on democratic principles, as well as citizen participation. The theoretical foundation for the analysis is provided by the theories by Tero Päivärinta and Øystein Sæbø, Joachim Åström, and Jan A. G. M. van Dijk. The paper is divided into several parts: the first one discusses the character of electronic democracy and its models, the second concerns the issue of ICT-assisted participation, and the third is devoted to the different dilemmas and challenges posed by electronic democracy.

\section{Definitions and models of electronic democracy}

When describing the influence of modern technologies on the democratic system, it should be noted that the literature on the subject reveals considerably different approaches to how 'electronic democracy' is comprehended. Lewis A. Friedland advocates an extensive understanding, where the "concept of 'electronic democracy' connotes a radically new form of democratic practice modified by new information technologies" (1996, p. 185). According to Paweł Wimmer, 'electronic democracy' is frequently named 'digital democracy,' 'cyberdemocracy' or 'technodemocracy' and can be understood as the application of electronic communication technology to strengthening democratic processes in the state (Wimmer, 2004).

'Electronic democracy' can be defined in terms of information and communication technologies applied in order to increase citizen participation in democratic processes, both as concerns the quantity and the form of actual impact exerted by individuals on public institutions (Marczewska-Rytko, 2010, p. 23). Despite the multitude of terms describing the changes brought about by new technologies applied in democracy, at present the term 'electronic democracy' seems to be most frequent. The popularity of this notion is evidenced by a considerable number of foreign publications (Browning, 2005; Kersting 2012; Noveck, 2004; Tsagarousianou, Tambini, Brian, 1998; Weale, Musso, Hale, 1999; Grossman, 1995; Tsagarousianou, 2000) accompanied by the increasing achieve- 
ments of Polish scholars investigating the subject of 'electronic democracy' (Porębski, 2012; Nowina Konopka, 2008; Białobłocki, Moroz, Nowina Konopka, Zacher, 2006; Musiał-Karg 2012; Łuszczuk, 2001).

The multitude of definitions and differences in comprehending specific terms (cyberdemoracy, electronic democracy, teledemocracy) evidences the terminological chaos concerning this term. The term 'electronic democracy' is not unequivocally interpreted in the literature, thereby resulting in definition turmoil instead of semantic order.

The following considerations adopt a broad perspective on how 'electronic democracy' is understood. The term comprises a form of practicing democracy by means of new information and communication technologies. 'E-democracy' is mostly about enabling the citizens of a given state to exert an impact on political decisions made in the course of direct and indirect democracy procedures by means of modern ICT. This approach is justified by Martin Hagen (1997), who reckons that this term is highly comprehensive and incorporates other, narrower senses of democracy.

One of the most noticeable consequences of using information and communication technologies in political life is the emergence of the term 'electronic democracy,' which directly refers to the evolution of this paradigm of democracy connected with the socalled new media. The role of ICT is so important that even some democracy theorists, such as Barry N. Hague or Brian Loader (1999), while introducing the term 'electronic democracy' ('e-democracy'), speak about a change in understanding the way the democratic system is perceived and defined today. The existence of the above definition of a new form of democracy, or talking about a new phenomenon in political life suggests a significant and inevitable shift in how democratic forms of exercising power in the modern world are distinguished. One of the oft-cited definitions of e-democracy was formulated by researchers Ken Hacker and Jan van Dijk (2000). They stated that 'electronic democracy' represents the use of information and communication technologies (ICTs) and computer mediated communication (CMC) in all kinds of media (e.g. the Internet, interactive broadcasting and digital telephony) for the purposes of enhancing political democracy or the participation of citizens in democratic communication. Lori Weber also states that 'e-democracy' is based on ICT and it has yet to take full advantage of technologies from the Internet (Weber, 2002, p. 1). It indicates that citizens are able to get most of their information from the Internet, which is a new situation when compared to previous methods in history (Browning, 2002). ICTs and the Internet now open up many possibilities for citizen participation. Tony Corrizales gives a very useful definition by Andrew and Nada Korac-Kakabadse, who wrote that electronic democracy is "the capacity for ICTs to enhance the degree and quality of public participation in government and highlight the possibility for direct-democracy on a large scale" (1999). Based on the considerations of Tony Corrizales, one may say that "e-Democracy also allows for greater government transparency and openness, which leads to a better-informed citizenry" (2008).

The analysis of the conceptual apparatus and considerations pertaining to "electronic democracy' lead to a highly interesting approach taken by Tero Päivärinta and Øystein Sæbø. Starting with the premise that new technologies alter the conditions of communication in socio-political life and increase interest in the application of new technologies, among other things in the field of citizen participation in political processes, the two 
scholars define 'e-democracy' as a form that refers to the application of information and communication technologies in political debates and decision-making processes. Päivärinta and Sæbø stress the fact that new (electronic) means of exerting political influence on the one hand supplement traditional means, and on the other, they counterbalance them (Päivärinta, Sæbø 2006, p. 818). Taking into account the dynamic development of ICTs, and their introduction to different fields of social life, it should be said that it seems more appropriate to perceive new technologies as elements that complement traditional forms. This can be supported by a number of initiatives to support e-democracy that have recently emerged. It is worth noting that electronic forms of governance are supported by both local (Grönlund, pp. 55-72; Sæbø, T. Päivärinta, 2005) and international communities (eEurope 2005,2002$)$, which cherish the hope that new technologies can potentially increase the level of democratization (Päivärinta, Sæbø, 2006, p. 818). Päivärinta and Sæbø take into consideration two factors: (1) who sets the political agenda, and (2) the extent to which citizens are involved in decision-making processes as regards the state, and on this basis identify four models of 'electronic democracy'.

Table 1

Models of e-democracy

\begin{tabular}{|l|l|l|}
\hline \multicolumn{1}{|c|}{ Citizens set the agenda } & \multicolumn{1}{c|}{ Partisan Democracy } & \multicolumn{1}{c|}{ Direct Democracy } \\
\hline $\begin{array}{l}\text { Government (politicians and } \\
\text { officers) sets the agenda }\end{array}$ & Liberal democracy & Deliberative democracy \\
\hline & $\begin{array}{l}\text { Citizens mainly implicitly included } \\
\text { in decision making processes }\end{array}$ & $\begin{array}{l}\text { Citizens have an explicitly defined } \\
\text { role in decision making processes }\end{array}$ \\
\hline
\end{tabular}

Source: Päivärinta, Sæbø, 2006, p. 823.

Partisan democracy emphasizes the fundamental importance of political parties for the ideas and practice of democracy (Saward, 2008, p. 177). According to T. Päivärinta and $\varnothing$. Sæbø, this model provides for citizen participation in decision-making processes only implicitly. "Partisan democracy initiatives are characterised by citizen-initiated participation and implicit citizen intervention in the decision-making process. Active citizens participate in the political debate, but not through traditional channels or solely through representatives. Information technology seeks to obtain visibility for alternative political expressions and criticism without interruptions from the political elite" (Päivärinta, Sæbø, 2006, p. 824).

In the case of the liberal democracy model, the political agenda is set by the government - politicians and officers. Michael Saward reckons that liberal democracy is closely related to the democracy of elite competition and representative democracy (Saward, 2008, p. 177) and may be described as government by representatives, where an electorate gives mandates to representatives at the local level but also participates in the public debate (Held, 1996).

As far as the concept of deliberative democracy is concerned, attention should be placed on the significant role attributed to dialogue, discussions and debates in democratic practice. The fact that a given decision is made in the course of a violence- and coercion-free process of weighing arguments is much more significant than voting as such. The most renowned theoreticians of the concept of deliberative democracy include Jürgen Habermas (1998; 2005; 1999; Baciak, 2006; Abramowicz, 2011) and John Rawls 
(Rawls, 1998; McCarthy, 1994; Buksiński, 2002), who emphasize that decision-making processes should be oriented towards discussion, dialogue and deliberation as the methods of shaping public desires and opinions.

As concerns the model of direct democracy, indicated by T. Päivärinta and Ø. Sæbø, it provides a very broad definition of citizens' function in political life: citizens play a considerable role in decision-making processes and set the political agenda.

All the above concepts are presented and described in Table 2, which also indicates three of the four above-mentioned models of democracy (with the exception of partisan e-democracy where no theoretical contributions are identified).

Table 2

\section{E-democracy models in relation to previous literature}

\begin{tabular}{|c|c|c|}
\hline 1 & 2 & 3 \\
\hline \multirow{6}{*}{ 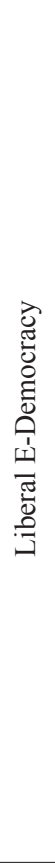 } & $\begin{array}{l}\text { Liberal and developmental de- } \\
\text { mocracy (Held, 1996) }\end{array}$ & $\begin{array}{l}\text { Representative government where citizens are involved via } \\
\text { voting, as representatives at the local level and participants in } \\
\text { public debate. }\end{array}$ \\
\hline & $\begin{array}{l}\text { Aggregative democracy (Eriksen } \\
\text { and Weigård, 1999) }\end{array}$ & $\begin{array}{l}\text { Politics is a fight between conflicting individual interests. Poli- } \\
\text { ticians are responsible for aggregating elector interests as they } \\
\text { occur via elections. }\end{array}$ \\
\hline & $\begin{array}{l}\text { Pluralism democracy (Held, } \\
\text { 1996, Van Dijk, 2000) }\end{array}$ & $\begin{array}{l}\text { Competitive electoral system with at least two parties secures } \\
\text { government by minorities and political liberty. Citizens have } \\
\text { the right to express their ideas, vote and organize. }\end{array}$ \\
\hline & $\begin{array}{l}\text { Competitive Elitist democracy } \\
\text { (Held, 1996)/Demo elitist de- } \\
\text { mocracy (Bellamy, 2000) }\end{array}$ & $\begin{array}{l}\text { Elected parliaments are the basis for the democracy. Experts } \\
\text { representing (or claiming to represent) different interests in so- } \\
\text { ciety act in policy networks. These political experts represent } \\
\text { the elite, which are intensively involved in the formation of } \\
\text { policy and definition of the public services. }\end{array}$ \\
\hline & $\begin{array}{l}\text { Legalist democracy (Held, 1996, } \\
\text { Van Dijk, 2000) }\end{array}$ & $\begin{array}{l}\text { The majority principle protects individuals from arbitrary gov- } \\
\text { ernments. Effective political leadership is guided by Liberal } \\
\text { principles, and there is a minimum state intervention in civil } \\
\text { society and private life. }\end{array}$ \\
\hline & $\begin{array}{l}\text { Consumer democracy (Bellamy, } \\
\text { 2000), Thin democracy (Aas- } \\
\text { tröm, 2001) }\end{array}$ & $\begin{array}{l}\text { The main democratic value resides in the citizen's right to } \\
\text { service. The model seeks to re-focus democracy around the } \\
\text { efficient provision of public services. Competent consumers } \\
\text { need to be well informed; implying an important role for infor- } \\
\text { mation and communication systems through which politicians } \\
\text { inform citizens. }\end{array}$ \\
\hline \multirow{3}{*}{ 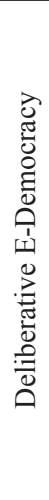 } & $\begin{array}{l}\text { Participatory democracy (Held, } \\
\text { 1996, Pateman, 1970, Van Dijk, } \\
\text { 2000) }\end{array}$ & $\begin{array}{l}\text { Equal rights can only be achieved in a participatory society } \\
\text { which fosters a sense of political efficacy. A knowledgeable } \\
\text { citizenry is capable of taking sustained interest in the govern- } \\
\text { ing process. Less power to bureaucracy in favour of more in- } \\
\text { volvement by the citizens. }\end{array}$ \\
\hline & $\begin{array}{l}\text { Neo-Republican democracy } \\
\text { (Bellamy, 2000)/Plebiscitary de- } \\
\text { mocracy (Van Dijk, 2000) }\end{array}$ & $\begin{array}{l}\text { Citizens are regarded as active, especially at micro- and lo- } \\
\text { cal levels. The model has radical assumptions on shared social } \\
\text { rights and responsibilities, where revitalization of civic spirit } \\
\text { is a central objective. ICT facilitates an increased number of } \\
\text { participants, highquality discussion and social inclusion in } \\
\text { decision-making. }\end{array}$ \\
\hline & $\begin{array}{l}\text { Deliberative democracy (Gimm- } \\
\text { ler, 2001), Strong democracy } \\
\text { (Barber, 1984, Aaström, 2001) }\end{array}$ & $\begin{array}{l}\text { Highlights the role of open discussion, the importance of citi- } \\
\text { zen participation, and the existence of a well-functioning pub- } \\
\text { lic sphere. }\end{array}$ \\
\hline
\end{tabular}




\begin{tabular}{|c|c|c|}
\hline 1 & 2 & 3 \\
\hline 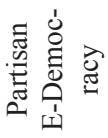 & & No theoretical contributions identified. \\
\hline \multirow{3}{*}{ 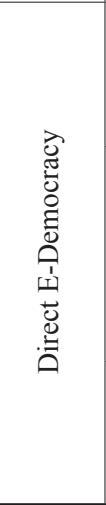 } & $\begin{array}{l}\text { Classical democracy (Held, } \\
\text { 1996) }\end{array}$ & $\begin{array}{l}\text { Citizens had political equality and were free to rule and be } \\
\text { ruled in turn. Main decisions were made by all in the assembly } \\
\text { with sovereign power. Citizens were admitted to participate in } \\
\text { politics focusing on society, not individuals. }\end{array}$ \\
\hline & $\begin{array}{l}\text { Direct democracy (Held, 1996, } \\
\text { Lynne, 2004)/Cyberdemocracy } \\
\text { (Bellamy, 2000) }\end{array}$ & $\begin{array}{l}\text { A radical alternative compared to the traditional democratic } \\
\text { institutions and features. Traditional institutions lose power } \\
\text { in favour of network-based groups and individuals. ICT no } \\
\text { longer represents a supplement to traditional communication } \\
\text { channels, emerging as a crucial pre-condition for democ- } \\
\text { racy. }\end{array}$ \\
\hline & $\begin{array}{l}\text { Libertarian democracy (Van } \\
\text { Dijk, 2000), Quick democracy } \\
\text { (Aaström, 2001) }\end{array}$ & $\begin{array}{l}\text { Emphasises the autonomous politics by citizens in their own } \\
\text { associations using the horizontal communication capabilities } \\
\text { of ICT. Traditional institutions is, in the most extreme applica- } \\
\text { tion, put aside by politics created in networks. }\end{array}$ \\
\hline
\end{tabular}

Source: Päivärinta, Sæbø, 2006, p. 839.

Joachim Åström presents interesting considerations on the types of electronic democracy, in an attempt to answer the question of whether democracy should be 'thin' and 'strong', the way Benjamin Barber understands it, or 'fast'. Åström takes into account such factors as the goal of democracy, the source of the legality of authorities, the role of citizens and the field in which ICT vehicles are applicable. The first type he distinguishes in 'thin democracy', where the voters' main task involves electing their representatives in parliamentary elections. Voters are subsequently informed about the decisions made by their representatives on their behalf.

In another type of e-democracy - 'strong democracy' - citizens permanently make decisions on issues presented by politicians. In this approach, the citizen-politician interaction becomes visible.

Types of electronic democracy

\begin{tabular}{|l|l|l|l||}
\hline & \multicolumn{1}{|c|}{ 'thin' 'strong' } & \multicolumn{1}{c|}{ 'fast' } \\
\hline Goal & $\begin{array}{l}\text { efficiency/possibility of } \\
\text { choice }\end{array}$ & consensus & power for the people \\
\hline Source of legality & settlement & public debate & majority principle \\
\hline Citizen's role & client & opinion-former & decision-maker \\
\hline $\begin{array}{l}\text { Authority of the elected } \\
\text { representative }\end{array}$ & free hand & interaction & obligation \\
\hline Basic application of ICT & information & discussion & decision \\
\hline
\end{tabular}

Source: Czajkowski, Kaczmarczyk, 2001, p. 48.

In a 'fast democracy' voters are the decision-makers - those on whom political decisions rely to the greatest extent (Musiał-Karg, 2010, pp. 127-128). 


\section{Graph 1. Different forms of democracy and ICT applied}

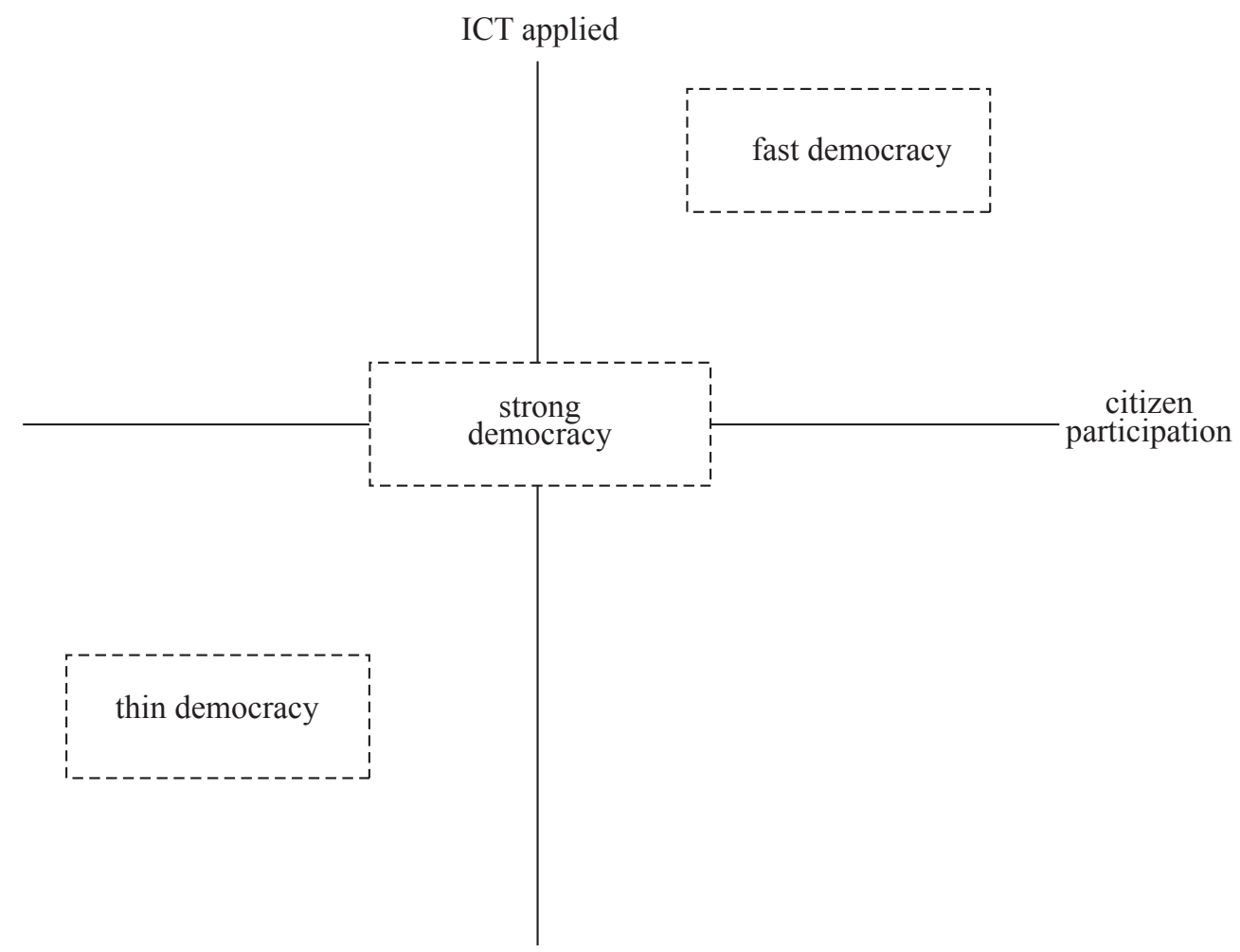

Source: Åström, 2001; see also: Prosser, Krimmer, 2004, p. 23.

Graph 1 illustrates all three of the above-mentioned types of electronic democracy. In the fast democracy, citizen involvement in decision-making processes increases on account of the use of ICTs, which, according to Åström, translates into an increased role of citizens in state governance and increased efficiency of democracy (Åström, 2001). In his typology, the same author rightly points to two significant properties that are considered essential for the development of e-democracy. Citizen involvement and the consequent efficiency of governance are indicative of the quality of democracy: the higher the index of each factor, the 'better' the democracy.

\section{E-participation}

Many theoreticians of ICT application perceive e-democracy as the higher participation of citizens who have new technologies at their disposal, thereby being able to become more involved in political processes, especially in a representative democracy. It needs to be pointed out, however, that the use of ICT in democracy brings about an evolution of (or restrictions on) the government's role, and thereby the expanded range or forms of citizen activities (forms of direct democracy) (Clift, 2003). 
Graph 2. The principal application of e-participation tools in political processes

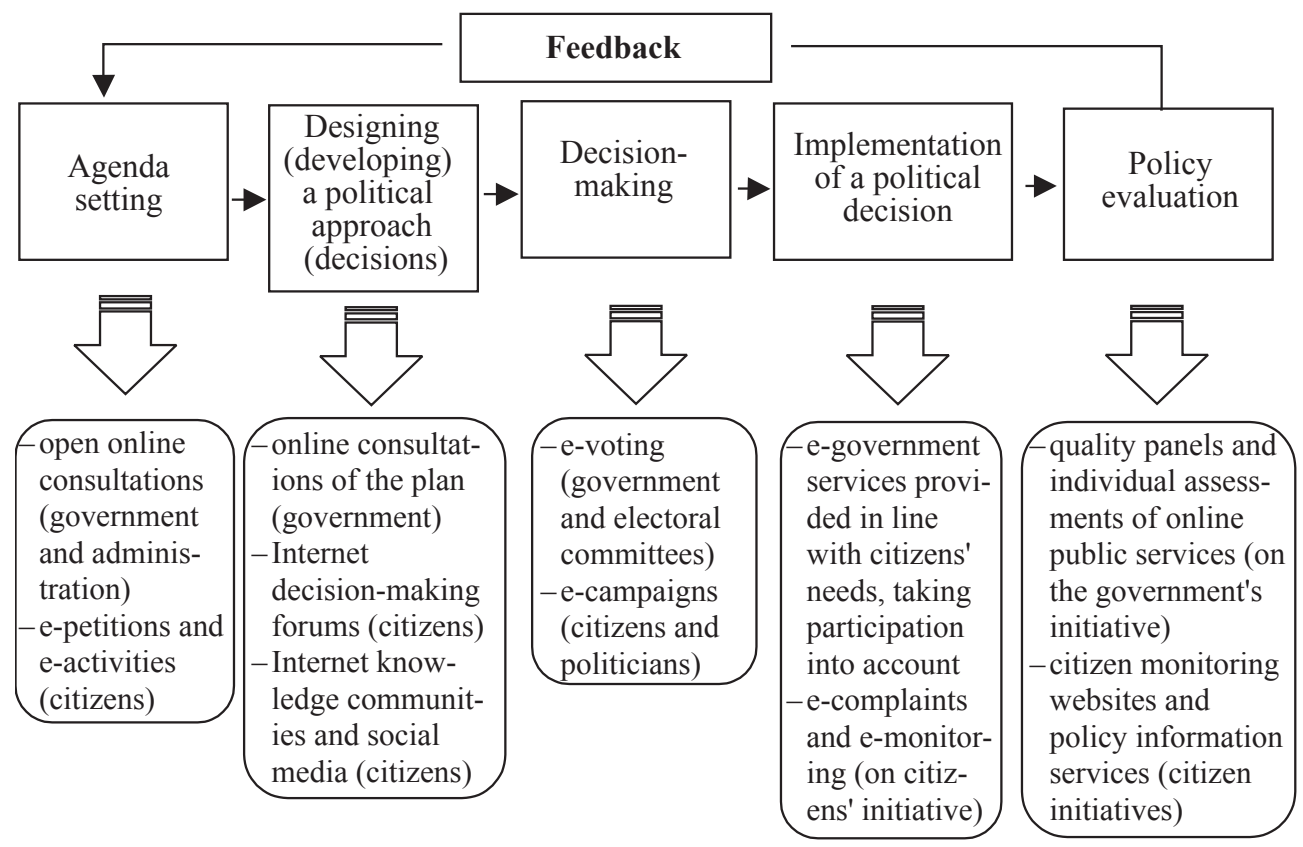

Source: Own study based on: van Dijk, 2012, p. 56.

The phenomenon of increased citizen involvement in political life via ICT is addressed by Jan A. G. M. van Dijk, who names these citizen activities electronic participation, and defines them as "the use of digital media to mediate and transform the relations of citizens to governments and to public administrations in the direction of more participation by citizens" (van Dijk, 2012, p. 56; van Dijk, 2010).

With respect to the different stages of political processes, van Dijk distinguishes a range of e-participation forms applicable in political decision-making. According to him, in the first stage, where the action plan (agenda) is set, the authorities notify citizens about their activities on official government websites, and invite them to comment on political undertakings, both those under way and planned. Although ICT tools are most often used to provide information to voters, only imparting information is insufficient to ensure e-participation as that requires citizen involvement. Therefore, more and more often, citizens are given the opportunity to exert an influence on the authorities, for instance via e-petitions. Technological advancement facilitates electronic consultations to be organized, discussions on online forums and in the social media, which van Dijk lists as part of the second stage of political processes, where a draft of a decision can be drawn up. Suggestions and comments posted by participants of such electronic forms of discussion can play a significant role when drawing up the final drafts of laws, or detailing the plans of politicians in a specific field (Katz, Rice, 2002; Brundige, Rice, 2009; ter Hedde, Svensson, 2009; van Dijk, 2006).

Speaking about decision-making and the use of ICT tools at this stage, two participation forms are mentioned: e-voting (in elections, referenda and public opinion polls) 
and election e-campaigns. When characterizing a further stage - policy implementation - van Dijk indicates that ICTs can be used by authorities in order to 'screen' the Internet for crime, but the authorities can also turn to citizens, asking them to report all kinds of infringements of the law and malfunctioning of public institutions, via such electronic tools as Internet websites, specific electronic urban kiosks and cellular telephony (for instance Fix My Street, http://www.fixmystreet.com/).

Forms of e-participation employed at the stage of policy assessment encompass, among other things, providing feedback to different institutions concerning the quality of services they render. Such tools are frequently used by local administration institutions and can bring about improvement in the quality of such services.

J. van Dijk notes that different e-participation forms are typically employed at the agenda setting and project development stages. The stage of policy assessment is yet another area of e-activities, primarily owing to initiatives by citizens and citizen organizations. In the case of decision-making and implementation, however, the use of e-participation seems quite limited; this may result from the fact that the authorities do not want to admit citizens to these stages. It is worth noting that resorting to the forms of e-participation at the stage of political decision-making is the ultimate test of their use in a democratic context. It has already been indicated, though, that the influence of e-tools that enhance citizen involvement is negligible in this area (van Dijk, 2010).

\section{Selected dilemmas and challenges related to e-democracy}

One of the essential issues mentioned in the context of considerations on e-democracy is that of unequal access to the infrastructure of new technologies, in particular to the Internet.

The observation that citizens are not equal in terms of access to the Internet seems banal. This inequality is produced by different levels of Internet infrastructure in different countries, and the different material status of different groups of voters. The phenomenon of unequal access to the Internet is usually named the 'digital divide' (or 'digital split'). Another term applied in this context is 'e-exclusion.'

The term 'digital divide' emerged in the early 1990s and initially described the division into those enjoying access to the Internet and those without it. The border between them also marked other social divisions: between rich and poor, educated and uneducated, younger and older, and between men and women. The early $21^{\text {st }}$ century saw the emergence of new definitions of the 'digital divide' which came to signify the gap between those with broadband Internet access, and those who do not have such access. The digital divide (digital gap) is frequently referred to as one of the greatest threats to the information society. The digital divide is about the social stratification resulting from electronic illiteracy that may be caused by economic conditions, the absence of technical potential, age, social status, disabilities, mental barriers or educational shortcomings.

The essence of the 'digital divide' is that individuals who for various reasons do not have access to the Internet are partly excluded from different dimensions of social life, which can breed many social conflicts. 
The issue of the digital gap is discussed by Pippa Norris. In her study, Digital Divide. Civic Engagement, Information Poverty, and the Internet Worldwide, Norris indicates three levels of this phenomenon (Norris, 2001). She stresses the global scale, where the 'digital divide' is caused by the global division into the north (which is developed and has extensive access to the Internet) and the south (with developing countries and limited access to the Internet). The second level Norris mentions is the social level, where the 'digital divide' is the outcome of material status. This phenomenon is present even in countries that are deemed to be developed and are leaders in terms of information society development. Individuals with low income levels cannot join the so-called network society there. Norris points to the report by the U.S. Department of Commerce, Falling through the Net, indicating disproportion in access to the Internet of groups with low income per household, those with lower education, Black Africans and Latinos, as well as dwellers of rural areas and, to a smaller extent, women (Falling through the Net...). The third level is about citizen participation, and this is described as a 'democratic divide.' This dimension is most interesting from the point of view of the considerations herein, as it concerns the division of citizens into two polarized groups: those who are actively taking advantage of the potential offered by the Internet in order to intensify their participation in public life, and those who are passive, and do not make an effort to participate in public life, even though they frequently have access to the Internet (Norris, 2001, p. 4; Maj, 2009, p. 199).

Answering the question of what factors are decisive for a digital gap to be present, for instance in terms of democracy, we should take into account the results of the analysis of ballots cast in the primaries organized by the Democratic Party in the United States in Arizona in 2000. These elections evidenced the fact that votes were cast via the Internet most often by better educated and younger voters. Additionally, the opportunity to cast votes electronically was much more frequently used by liberal men. Women and conservative voters used the net less frequently in order to participate in political decision-making (Tolbert, Mossberger, 2006, pp. 3-4; Mossberger, Tolbert, Stansbury, 2003, p. 92). In the context of the 'democratic divide,' one of the causes of that may also be related to material differences within society, where people with lower incomes simply cannot afford to purchase computers, and they consequently are excluded from the network society and are deprived of the possibility to use the Internet as an instrument of participation in political life.

Another significant and widely debated aspect concerns freedom, or - to be more specific - freedom of speech. On account of the new media used in public life, freedom of speech also assumes a new dimension. These changes concern, for instance, election silences imposed in many countries in order to provide quiet conditions for voters to think over and make electoral decisions, free from political campaigning. It should be borne in mind here that the ban on political campaigning is in many countries (including the US) identified with the lack of democratic standards of freedom of speech and freedom to communicate. In the time of the Internet, there are numerous instances of the breaching of election silences (introduced in many Central and East European countries) which can be seen in all kinds of online websites, political blogs, Internet forums and the highly popular social media. It is therefore reasonable to ask about the justification for maintaining an election silence which is highly difficult to observe in the age of the 
Internet. This issue is becoming yet more important in the context of electronic voting, because, in this case, Internet forums can become an area of struggle between competing political parties and politicians.

The principle of transparency consists in the clarity and openness of state policy as perceived by citizens. It can be ensured by an appropriate information policy providing all possible details on the functioning of public institutions, their strategies, initiatives they are planning and implementing, decision-making mechanisms and processes, as well as the essential decisions pertaining to society and made by public institutions. Przemysław Maj remarks that the "principle of transparency pertains to the entire political system and means the transparency of operating procedures at all levels of authorities as well as the non-state public area, in particular political parties" (Maj, 2009, p. 217).

The principle of transparency in the Internet is primarily about providing social access to all kinds of information about political parties, politicians, their statements, voting, initiatives and decisions made in representative bodies. The Internet facilitates political, legal and financial transparency primarily by way of posting concrete and factual details on appropriate websites. Such information is typically available on the sites of specific state institutions, political parties and politicians. Maj stresses also the issue of legal transparency (access to legal procedures, to important legal regulations pertaining to social life and internal standards of institutions, such as statutes and regulations) and financial transparency (public access to the details of the sources and amounts of income of officials and politicians). The transparency of decision-making and authorities' activities should be deemed to be a citizen right, and exercising the right to transparency is one of the fundamental purposes of the Internet and other new technologies in modern democracies (Musiał-Karg, 2013, pp. 91-92). It should be noted, however, that there are concerns as to the credibility of information published on the Internet. It is true that, on the one hand, the Internet serves the purpose of disseminating information (thereby facilitating the implementation of the principle of transparency of the authorities and their activities), but on the other, it can be susceptible to manipulation. Piotr Lissewski notes that this is caused by machines and software replacing humans in the verification process (Lissewski, 2002, p. 117). Another considerable concern is raised by the issue of anonymity in the Internet, which is highly important in the context of the implementation of e-voting systems, among other things.

\section{Concluding remarks}

Summing up the considerations on the impact of ICT on democracy and the political space, one should admit that the new media - particularly the Internet - have become an enormously important tool in the interactions of the participants of political life. Undoubtedly, this is a consequence of the fact that the application of information and communication technologies allows the barriers connected with the distance between voters and those who govern, or who represent those governing, to be removed.

It should also be added that the rapid growth of the Internet affects modern civilization and changes the characteristics of interpersonal relations, communication methods, the way of doing politics, and may contribute to the emergence of a new quality in social 
life. The examples provided in this paper confirm that ICT tools have the potential to improve people's involvement in politics, through, for example, access to the official websites of institutions, politicians or political parties, electronic citizen forums or electronic voting. Despite many drawbacks, many politicians and practitioners state that modern technologies will increasingly be applied in political communications and in processes in the political market. That requires the ongoing education of citizens to participate in politics, which seems to be one of the most important challenges.

\section{Bibliography}

Abramowicz B. (2011), Koncepcja demokracji deliberacyjnej jako odpowiedź na postulaty usprawnienia demokracji przedstawicielskiej, „Ruch Prawniczy, Ekonomiczny i Socjologiczny”, LXXIII, Issue 4.

Åström J. (2001), Should Democracy Online be Quick, Strong, or Thin?, "Communications of the ACM", vol. 44, no. 1, http://www.accessmylibrary.com/coms2/summary_0286-10566163_ITM, 14.11.2015.

Baciak P. (2006), Internet - Agora XXI wieku? Rozważania w świetle teorii demokracji deliberatywnej autorstwa Jürgena Habermasa, "Global Media Journal-Polish Edition”, no. 2 (2)/Fall.

Barber B. R. (1984), Strong democracy: participatory politics for a new age, University of California Press, Berkeley.

Bellamy C. (2000), Modelling electronic democracy, Towards democratic discourses for an information age, in: Democratic governance and new technology, technologically mediated innovations in political practice in Western Europe, eds. J. Hoff, I. Horrocks, P. Tops, Rutledge, London.

Browning G. (2005), Electronic Democracy. Rusing the Internet to Transform American Politics, Bedford-New Jersey.

Browning G. (2002), Electronic Democracy: Using the Internet to Transform American Politics, Medford.

Brundige J., Rice R. (2009), Political engagement online: do the information rich get richer and the like-minded more similar?, in: Routledge Handbook of Internet Politics, red. A. Chadwick, P. H. Howard, London-New York.

Buksiński T. (2002), Dylematy demokracji deliberatywnej Johna Rawlsa i Jürgena Habermasa, in: Rozum jest wolny, wolność - rozumna, eds. R. Marszałek, E. Nowak-Juchacz, Warszawa.

Carrizales T. (2008), Critical Factors in an Electronic Democracy: a Study of Municipal Managers, "The Electronic Journal of e-Government", vol. 6, Issue 1.

Clift S. (2003), E-Democracy, E-Governance and Public Net-Work (Government 2.0) - Overview, http://stevenclift.com/?p=104, 13.11.2012.

Czajkowski R., Kaczmarczyk A. (2001), E-głosowanie - niezbędny element elektronicznej platformy do obstugi procedur demokracji w spoteczeństwie informacyjnym, in: Tworzenie mechanizmów i struktur rozwoju elektronicznej gospodarki w Polsce. Warszawa, 12 czerwca 2001 r. Conference Materials, Instytut Logistyki i Magazynowania, Poznań.

Digital Democracy: Issues of Theory and Practice (2000), eds. K. L. Hacker, J. van Dijk, London.

eEurope 2005: An information society for all. An Action Plan to be presented in view of the Sevilla European Council, 21/22 June 2002, Commision of the European Communities, http://eur-lex. europa.eu/LexUriServ/LexUriServ.do?uri=COM:2002:0263:FIN:EN:PDF, 12.12.2011.

Eriksen E. O., Weigård J. (1999), Kommunikativ handling og deliberativt demokrati: Jürgen Habermas'teori om politikk og samfunn, Fagbokforlaget, Bergen. 
Falling through the Net. Defining the Digital Divide. A Report on the Telecommunications and Information Technology Gap in America, July 1999, National Telecommunications and Information Administration, Department of Commerce.

Friedland L. A. (1996), Electronic Democracy and the New Citizenship, „Media, Culture \& Society”, vol. 18 , no. 2.

Gimmler A. (2001), Deliberative democracy, the public sphere and the internet, "Philosophy Social Criticism", no. (27) 4.

Grossman L. K. (1995a), Maintaining Diversity in the Electronic Republic, “Technology River”, vol. 98.

Grossman L. K. (1995b), The Electronic Republic. Reshaping Democracy in the Information Age, New York.

Grönlund Å. (2003), Emerging electronic infrastructures - Exploring democratic components, "Social Science Computer Review", no. 1 (21).

Habermas J. (1998), Between Facts and Norms. Contributions to a Discourse Theory of Law and Democracy, Cambridge.

Habermas J. (2005), Faktyczność i obowiqzywanie. Teoria dyskursu wobec zagadnień prawa i demokratycznego państwa prawnego, Warszawa.

Habermas J. (1999), Teoria działania komunikacyjnego, Tom I, PWN, Warszawa.

Habermas J. (2002), Teoria działania komunikacyjnego, Tom II, Warszawa.

Hague B. N., Loader B. (1999), Digital Democracy: Discourse and Decision-making in the Information Age, New York.

Held D. (1996), Models of Democracy, Blackwell, Oxford.

Katz J., Rice. R. (2002), Social Consequences of Internet Use, Access, Involvement, and Interaction, London.

Kersting N. (2012), The Future of Electronic Democracy, in: Electronic Democracy, ed. N. Kersting, Opladen-Berlin-Toronto.

Korac-Kakabadse A., Korac-Kakabadse N. (1999), Information Technology's Impact on the Quality of Democracy: Reinventing the 'Democratic Vessel, in: Reinventing Government in the Information Age: International Practice in IT-Enabled Public Sector Reform, ed. R. Heeks, London.

Lissewski P. (2002), Cyberdemokracja? Internetowe iluzje, „Przegląd Politologiczny”, no. 3.

London S. (1995), Teledemocracy vs. Deliberative Democracy? A Comparative Look at Two Models of Public Talk, ,Journal of Interpersonal Computing and Technology”, vol. 3, no. 2.

Lynne E. (2004), Direkte demokrati, Pax, Oslo.

Maj P. (2009), Internet i demokracja. Ewolucja systemu politycznego, Wydawnictwo Uniwersytetu Rzeszowskiego, Rzeszów.

Marczewska-Rytko M. (2010), Idea demokracji bezpośredniej od okresu antycznego do czasów Internetu i globalizacji, in: Demokracja bezpośrednia. Wymiar globalny lokalny, eds. M. Marczewska-Rytko, A. K. Piasecki, UMCS, Lublin.

McCarthy Th. (1994), Kantian Constructivism and Reconstructivism: Rawls and Habermas in Dialogue, „Ethics”, no. 105.

Mossberger K., Tolbert C. J., Stansbury M. (2003), Virtual Inequality: Beyond the Digital Divide, Washington D.C.

Musiał-Karg M. (2009), Demokracja a Internet - doświadczenia Szwajcarii i Polski, in: Jednostka - spoleczeństwo - państwo wobec megatrendów wspótczesnego świata. Polska pięć lat w Unii Europejskiej, eds. G. Piwnicki, S. Mrozowska, Gdańsk.

Musiał-Karg M. (2013), Elektroniczne głosowanie. Wybrane dylematy wokół e-voting, in: Demokracja elektroniczna. Kontrowersje i dylematy, ed. M. Marczewska-Rytko, UMCS, Lublin.

Musiał-Karg M. (2012), Elektroniczne referendum w Szwajcarii. Wybrane kierunki zmian helweckiej demokracji bezpośredniej, Wydawnictwo WNPiD UAM, Poznań. 
Musiał-Karg M. (2010), Głosowanie elektroniczne - nowe wyzwanie dla demokracji?, „Przegląd Politologiczny", no. 4.

Norris P. (2001), Digital Divide. Civic Engagement, Information Poverty, and the Internet Worldwide, Cambridge.

Noveck B. S., Paradoxical Partners: Electronic Communication and Electronic Democracy, in: The Internet, Democracy and Democratization, ed. P. Ferdinand, Routledge.

Pateman C. (1970), Participation and democratic theory, Cambridge University Press, Cambridge.

Päivärinta T., Sæbø Ø. (2006), Models of E-Democracy, "Communications of the Association for Information Systems", vol. 17.

Prosser A., Krimmer R. (2004), The Dimensions of Electronic Voting. Technology, Law, Politics and Society, in: Electronic Voting in Europe-Technology, Law, Politics and Society. Workshop of the ESF TED Programme together with GI and OCG July, 7th-9th, 2004 in Schloß Hofen/Bregenz, Lake of Constance, Austria, eds. A. Prosser, R. Krimmer, Bonn.

Rawls J. (1998), Liberalizm polityczny, transl. A. Romaniuk, Warszawa.

Saward M. (2008), Demokracja, Warszawa.

Sæbø Ø., Päivärinta T. (2005), Autopoietic Cybergenres for e-Democracy? Genre analysis of a WebBased Discussion Board, in: Proceedings of the $38^{\text {th }}$ Annual Hawaii International Conference on System Sciences; Genre in Digital Documents, ed. R. H. J. Sprague, Hawaii: IEEE Computer Society, Big Island.

ter Hedde M., Svensson J. (2009), Online Discussion on Government Websites: Fact and Failure?, in: ICT, Citizens and Governance: After the Hype!, eds. A. Meijer, K. Boomsma, P. Wagenaar, Amsterdam-Berlin-Tokio.

The statement of the Internet Society Poland (ISOC) concerning e-voting in general elections, adopted by the ISOC Management Board on 10th January 2007 (Resolution of the ISOC Poland Management Board No. 2/2007), January 1st, 2007, Internet Society Poland, http://www.isoc.org. $\mathrm{pl} / 200701 /$ wybory, 13.04.2014.

Tolbert C. J., Mossberger K. (2006), New Inequality Frontier: Broadband Internet Access, Economic Policy Institute Working Paper No. 275, Washington.

Tsagarousianou R. (2000), Electronic Democracy in Practice: One, Two, Three... Countless Variants, "HERMÈS", no. 26-27.

Tsagarousianou R. (1999), Electronic democracy: Rhetoric and reality. Communications, "The European Journal of Communication Research", vol. 24, no. 2.

Tsagarousianou R., Tambini D., Brian C. (1998), Electronic Democracy and the Civic Networking Movement in Context, in: Cyberdemocracy. Technology, Cities and Civic Network, eds. R. Tsagarousianou, D. Tambini, C. Brian, Rotledge, New York.

van Dijk J. A. G. M. (2012), Digital Democracy: Vision and Reality, in: Public Administration in the Information Age: Revisited, eds. I. Snellen, M. Thaens, W. van de Donk, IOS-Press, AmsterdamBerlin-Tokio-Washington, DC.

van Dijk J. (2000), Models of democracy and concepts of communication, in: Digital Democracy, Issues of theory and practice, eds. K. L. Hacker, J. Van Dijk, London.

van Dijk J. A. G. M. (2010), Participation in Policy Making, in: Study on the Social Impact of ICT. Report for European Commission, Information Society and Media Directorate- General, European Communities DOI, Luxemburg, ec.europa.eu/, 17.09.2012.

van Dijk J. (2006), The Network Society, Social Aspects of New Media, London-Thousand Oaks-New Delhi.

Weale Ch., Musso J., Hale M. (1999), Electronic Democracy and the Diffusion of Municipal Web Pages in California, "Administration \& Society", vol. 31, no. 1. 
Weber L. (2002), A Survey of the Literature on the Internet and Democracy, Paper Presented at the Prospects for Electronic Democracy Conference, Carnegie Mellon University, Pittsburgh.

Wimmer P. (2004), Elektroniczna demokracja, http://www.ucze.p1/InternetDemocracy.htm, 22.10.2008.

\section{Wpływ ICT na współczesną demokrację. Wybrane dylematy wokół demokracji elektronicznej}

\section{Streszczenie}

Ze względu na szybki rozwój technologii informacyjnych i komunikacyjnych we wszystkich dziedzinach życia publicznego, wpływ ICT na demokrację staje się w ostatnich latach coraz bardziej popularnym przedmiotem badań wśród przedstawicieli nauki. Zastosowanie nowoczesnych technologii jest bardzo widoczne w gospodarce, edukacji, bankowości, usługach, przejawiając się zarówno w przestrzeni publicznej, jak i prywatnej. ICT są również stosowane w celu ułatwienia/usprawnienia procesów zachodzących pomiędzy instytucjami politycznymi, partiami politycznymi i politykami a wyborcami. W życiu politycznym nowoczesne technologie są stosowane zarówno w procesie informowania, w komunikowaniu, jak w procesie wyborczym.

W związku z powyższym mówić można o nowym paradygmacie demokracji wspomaganej przez technologie elektroniczne. Obok demokracji rozumianej w tradycyjny sposób, demokracja elektroniczna staje się popularnym pojęciem definiowanym w kategoriach technologii informacyjnych i komunikacyjnych stosowanych w celu zwiększenia udziału obywateli w procesach demokratycznych.

Głównym celem rozważań podjętych w niniejszym tekście jest odpowiedź na pytanie dotyczące najważniejszych dylematów związanych z e-demokracją oraz wybranych wyzwań pojawiających się $\mathrm{w}$ związku z tą nową formułą sprawowania władzy. Wywód prowadzony jest w kontekście wpływu ICT na zasady demokratyczne, jak i na udział obywateli w demokratycznym procesie decyzyjnym. Podstawą teoretyczną do analizy są ujęcia e-demokracji sformułowane przez następujących badaczy: Tero Päivärinta i Øystein Saebo, Joachim Åström i Jan A. G. M. van Dijk. Artykuł podzielono na kilka części: pierwsza dotyczy zdefiniowania demokracji elektronicznej i jej modeli, druga część poświęcona została kwestiom uczestnictwa wspieranego przez ICT, a w trzeciej części rozważań podniesiono zagadnienie różnych dylematów i wyzwań pojawiających się w związku z nowymi możliwościami e-demokracji.

Slowa kluczowe: demokracja elektroniczna, e-demokracja, ICT, e-partycypacja 
